\title{
Analysing the Sway of Cash Instruments in the Indian Financial Market Context
}

\author{
${ }^{*}$ Mrs. Bhumi Mehta \\ Former PhD Scholar, Pacific University, Udaipur, Rajasthan (India)
}

\begin{abstract}
There are basically four types of financial instruments viz: a bank deposit, a bill of exchange, a bond, and equity. As a result of a steady stream of financial innovations in today's time, the market landscape is far less sparse-and far more complex to evaluate.
\end{abstract}

Financial instruments are termed as the financial products which are tradable as packages of capital, each having their own unique characteristics and structure. The wide collection of financial instruments in today's marketplace allows for the efficient flow of capital amongst the world's investors. Financial instruments are legal documents that embody monetary value. There are a number of different types of documents that are properly identified as a financial instrument. There are different types of financial instrument, like cash instruments or derivative instruments.

Keywords: Cash instruments, Financial Market, Stock exchange

\section{Article Publication}

Published Online: 30-Jun-2021

\section{*Author's Correspondence}

8 Mrs. Bhumi Mehta

9 Former PhD Scholar, Pacific University, Udaipur, Rajasthan (India)

$\triangle$ bhumee.mehta5221@gmail.com

(C) 2021The Authors. Published by

International Journal of Management and Development Studies

This is an open access article under the

CC BY-NC-ND license

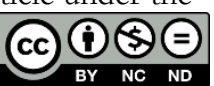

(https://creativecommons.org/licenses/b y-nc-nd/4.0/)

\section{Introduction:}

The Indian financial market is divided in two parts: capital market and money market. Both markets consist their own financial instrument to work out. Money market instruments take care of the borrowers' shortterm needs and render the required liquidity to the lenders.

This paper is mainly about cash instruments, one type of financial instrument available in Indian financial market. Unlike the interbank deposits, the certificates of deposits (CD), commercial papers and federal saving bonds are negotiable instruments, which can be traded in the secondary market before the end of the whole term. The primary goal of this paper is to highlight the importance of cash instrument in Indian financial market, along with the issues and challenges for this instrument due to changes in the financial scenario during last decade.

Cash instruments are financial instruments whose value is determined directly by markets. They can be divided into securities, which are readily transferable, and other cash instruments such as loans and deposits, where both borrower and lender have to agree on a transfer. This type of financial instrument is simply those documents that are recognized as cash that can be utilized for various transactions. Currency is the most easily identified of all cash instruments, although such documents as checks or funds transfers from bank accounts would also be understood to be a financial instrument of this type.The various types of cash instruments are as under:

- Certificate of Deposits (CD's) - A certificate of deposit is a borrowing note for the short-term just similar to that of a promissory note. The bearer of a certificate of deposit receives interest. The maturity date, fixed rate of interest and a fixed value - are the three components of a certificate of 
deposit. The term is generally between 3 months to 5 years. The funds cannot be withdrawn instantaneously on demand, but has the facility of being liquidated, if a certain amount of penalty is paid. The risk associated with certificate of deposit is higher and so is the return (compared to Tbills) is also high. One can earn more as compared to depositing money in savings account. The limitation is-The money is tied up along with the long maturity period of the Certificate of Deposit. Huge penalties are paid if one gets out of it before maturity.

- Commercial Papers (CP) - These are basically short-term bonds. The issuer of a CP has to pay the capital with the interest to bearer at maturity. For the companies, commercial papers act as "securitization", that is, they can borrow without using their bank deposits. Mainly, the investment banks issue the commercial papers. They are also known as promissory notes which are unsecured and are generally issued by companies and financial institutions, at a discounted rate from their face value. The fixed maturity for commercial papers is 1 to 270 days. The return on commercial papers is always higher than that of T-bills. Companies which have a strong credit rating, usually issue CPs as they are not backed by collateral securities.

- Treasury Bills -Treasury bills are short-term financial instruments that are issued by the Central Bank of the country. It is one of the safest money market instruments as it is void of market risks, though the return on investments is not that huge. Treasury bills are circulated by the primary as well as the secondary markets. The maturity periods for treasury bills are respectively 3 -month, 6-month and 1year. The price with which treasury bills are issued comes separate from that of the face value, and the face value is achieved upon maturity. On maturity, one gets the interest on the buy value as well.

- Call /Notice- In the Money Market Call/Notice money is the money borrowed or lent on demand for a very short period. When money is borrowed or lent for a day, it is known as Call (Overnight) Money. Intervening holidays and/or Sunday are excluded for this purpose. Thus money, borrowed on a day and repaid on the next working day, (irrespective of the number of intervening holidays) is "Call Money". When money is borrowed or lent for more than a day and up to 14 days, it is "Notice Money".

- Inter-Bank Term Money - Inter-bank market for deposits of maturity beyond 14 days is referred to as the term money market. The entry restrictions are the same as those for Call/Notice Money except that, as per existing regulations, the specified entities are not allowed to lend beyond 14 days.

- Loan and Deposits- The other popular cash instruments are loan and deposits facilities provided by the banks and other financial institutions for short term.

\section{Sway of Cash Instrument in Indian Financial Market}

Cash instrument plays significant role for trade, commerce and financial system in Indian financial market. Cash is the base for all economic activities. Its proper quantity is the fundamental requirement of the economy to grow. The role of cash instruments in Indian economies are:

- It is an important source of financing trading which a back bone for any country.

- Cash instrument are generally highly liquid and therefore can be used, even by institution with very long-term liabilities, in order to meet immediate cash flow needs (expenses, paying out benefits funds held for investment in longer-term instruments etc.)

- If an investor has just received a large amount, it will not necessarily be invested immediately and cash balance might increase. However, these cash balance should be held together with derivatives so that the investor is exposed to investment market movements, even if investment themselves are not held.

- Institutions with short term liabilities, such as banks and non-life insurance companies will hold short term cash instrument that appropriately match their liabilities. 
- Investor who believes that the prices in other asset markets are over-valued may hold cash instruments so that they are less than fully invested if there should be a fall in market values.

- It is an effective instrument for implementation of Monetary Policy.

- The development of cash instrument is the base for the development of Money Market.

- It offers avenues for commercial bank for investing short term surplus of funds and a borrowing for short term needs so as to meet statutory requirement of CRR and SLR.

- It serves as an important guide to the Govt. in formulating, revising and implementing its Economic policies like Credit policy, Fiscal policy and Monetary Policy.

\section{Challenges and Issues}

The Indian Money Market does not satisfy the criteria of a developed money market. It suffers from several of defects of system numerated as under:

- The performance of the cash instruments is heavily dependent on real interest rate that is the interest rate that is inflation adjusted. Though the money market is free from interest rate ceilings, structural barriers and other institutional factors can be held responsible for creating distortions in India Money Market. Apart from the call market rates, the other interest rates in the Indian Money Market usually do not change in the short run.

- Absence of Integration: The Indian money market is broadly divided into the Organized and Unorganized Sectors. The former comprises the legal financial institutions backed by the RBI. The unorganized statement of it includes various institutions such as indigenous bankers, village money lenders, traders, etc. There is lack of proper integration between these two segments.

- Multiple rate of interest: In the Indian money market, especially the banks, there exist too many rates of interests. These rates vary for lending, borrowing government activities, etc. Many rates of interests create confusion among the investors.

- Insufficient Funds or Resources: The Indian economy with its seasonal structure faces frequent shortage of financial recourse. Lower income, lower savings, and lack of banking habits among people are some of the reasons for it.

- Shortage of Investment Instruments: In the Indian money market, various investment instruments such as Treasury Bills, Commercial Bills, Certificate of Deposits, Commercial Papers, etc. are used. But taking into account the size of the population and market these instruments are inadequate.

- Shortage of Commercial Bill: In India, as many banks keep large funds for liquidity purpose, the use of the commercial bills is very limited. Similarly, since a large number of transactions are preferred in the cash form the scope for commercial bills are limited.

\section{Conclusion}

The life of the cash securities is normally short but the important features is the frequency with which interest rates change to take account of changes in short term interests; a floating rate note may have a long maturity but be a cash instrument because the interest it pays is tied to short term interest rates. The rate of interest on securities markets cash investment will not be fixed for more than a year and will normally be adjusted to reflect change in short term interest rates frequently. The cash instrument may take form of bank deposits or be tradable securities. A lot of steps are taken by the government to improve the situation of cash instrument in India like regulation of interest rate, establishment of the DFI, Liquidity adjustment facility, and Electronic transactions, Establishment of the CCIL and development of new financial instruments and there is always a scope for improvement. 


\section{References}

http://kalyan-city.blogspot.com/2010/09/indian-money-market-features-drawbacks.html http://www.articlesbase.com/finance-articles/overview-of-indian-money-market-

834329.html\#ixzz1GYWYDPn6

http://www.answers.com/topic/financial-instrument

http://finance.mapsofworld.com/finance/instrument/cash.html

http://www.articlesbase.com/finance-articles/overview-of-indian-financial-system-

836129.html\#ixzz1GYSrKOHp

http:/ / www.articlesbase.com/finance-articles/overview-of-indian-money-market-

834329.html\#ixzz1GYY6w8zH

Attributionhttp://www.articlesbase.com/finance-articles/overview-of-indian-money-market-

834329.html\#ixzz1GYWYDPn6

http://www.articlesbase.com/finance-articles/overview-of-indian-money-market-834329.html

http://business.mapsofindia.com/india-market/money.html.

http://www.staff.city.ac.uk/p.booth/Cashnotes.pdf

Agarwal and Agarwal- Financial market operations pp 381-400.

V. K. Mishra - Financial market operation pp 120-128 